\title{
E-Dakwah Islam Digest Republika.Co.Id. di Indonesia
}

\author{
Ujang Saepullah ${ }^{1 *} \&$ Khoiruddin Muchtar ${ }^{2}$ \\ ${ }^{12}$ UIN Sunan Gunung Djati Bandung, Indonesia \\ *email.ujang.saefullah@uinsgd.ac.id
}

\begin{abstract}
The research aims to analyze and understand the vision and mission of E-Da'wah, sources of content that are used as a reference, selected preaching content, and language style displayed in Islam Digest Republika.co.id. The research uses a case study method, a qualitative approach, using new media theory, and information dissemination theory. The research results show that the vision carried out by Republika.co.id's Digest Islamic Digest is modern, moderate, Muslim, nationality, and populist, with a mission as an advanced, intelligent, and civilized new online media. While the sources of the Islamic Digest news are taken from the primary causes of the teachings of Islam al-Quran Hadith and the works of classical and contemporary scholars. Likewise, the selected content around aqidah, sharia, Sufism, history, and others, by displaying popular language styles that are interesting and easy to read.
\end{abstract}

Keywords: da'wah communication, e-da'wah, islam digest

\begin{abstract}
ABSTRAK
Penelitian bertujuan untuk menganalisis dan memahami visi misi E-Dakwah, sumbersumber konten yang dijadikan rujukan, konten-konten dakwah yang dipilih dan gaya bahasa yang ditampilkan dalam Islam Digest Republika.co.id. Penelitian menggunakan metode studi kasus, pendekatan kualitatif, dengan menggunakan teori media baru dan teori penyebaran informasi. Hasil Penelitian menunjukan bahwa visi yang diemban EDakwah Islam Digest Republika.co.id adalah modern, moderat, muslim, kebangsaan, dan kerakyatan, dengan misi sebagai media online masyarakat baru yang maju, cerdas, dan beradab. Sedangkan sumber-sumber berita Islam Digest diambil dari sumber pokok ajaran Islam al-Quran Hadits dan karya-karya ulama klasik dan kontemporer. Demikian pula konten-konten yang dipilih sekitar aqidah, syariah, akhlak tasawuf, sejarah, dan yang lainnya, dengan menampilkan gaya bahasa populer yang menarik dan enak dibaca.
\end{abstract}

Kata Kunci: Komuikasi Dakwah, E-Dakwah, Islam Digest 


\section{INTRODUCTION}

The missionary communication movement in the millineal era is not only done with the preaching bil-qaul or bil-lisan but preaching through online media is more relevant and has a wider and worldwide reach. The millennial generation is filled by young people who are considered to have a high level of intimacy with new mass media such as the internet. Thus, it allows for dynamics in the process of transmitting Islamic messages. Especially by utilizing new media with various advanced features. Rustandi \& Hanifah (2019) view that da'wah among millennials takes place dynamically and can use contemporary media platforms with popular messages. It is at this point that the dynamics of da'wah will be more progressive among Islamic teenagers.

One of the national newspapers which has the concept and vision of this mission is Republika.co.id. Republika.co.id as an Islamic media channel is a continuation of the Republika Public Daily based on print media. One of the concepts offered is the existence of rubric E-Da'wah. The concept of E-Da'wah conducted by Republika.co.id. has gone a long way before other media do the same thing. Precisely the Republika General Daily launched the E-Da'wah Islamic Digest in 2010.

The launching of the E-Da'wah was assumed to meet the needs of a Muslim audience that is widespread throughout the country which is online media literacy. The online media is being loved by all levels of society, both the millennial and the elders, both the upper class and the middle class and lower class, both urban and rural communities. The heterogeneity of the community, almost every time they use the internet through gadgets, cellphones, laptops, and computers.

Yuswohadi and Gani said that the internet has now become part of the lifestyle of the Indonesian middle class. In everyday life, the middle class can hardly be separated from the internet. The internet is not only a loyal modern man, wherever he goes it is certain to always carry a smartphone, gadget, or cellphone. Once he or we don't carry a cellphone, then it looks like we will be overwhelmed and lose confidence. As if the internet at this time, has become a god for some people, because the definition of god according to Affred Tarski (1961) in the book, "Introduction to Logic" is something that is loved by us and we are dominated by it, that's God (Atmadja \& Ariyani, 2018: 153).

Thus, modern humans today, can not be separated from the ownership of cellphones, smartphones or gadgets, because almost everyone has a dependency on the internet which is accessed by us all the time. Whatever we need is on the internet, both positive and negative, there is the internet. We need the latest information about the world, on the internet, we need about knowledge on the internet, about everything on the internet, about economics, politics. Including 
about religion or religious practices on the internet, so it is known as religion online.

The latest survey results of APJII (Association of Indonesian Internet Service Providers) in 2018, reported that Indonesian internet users based on age, can be seen the following picture: The results of the latest APJII survey (Association of Indonesian Internet Service Providers) in 2018, reported that Indonesian internet users based on age, can see the following picture:

Figure 1 Group of Internet Users based on Age in Indonesia

\section{Pengguna Internet Berdasarkan Kelompok Usia (2017)} Sumber : Asosiasi Penyelenggara Jasa lnitemet findonesia (APJII), 2018

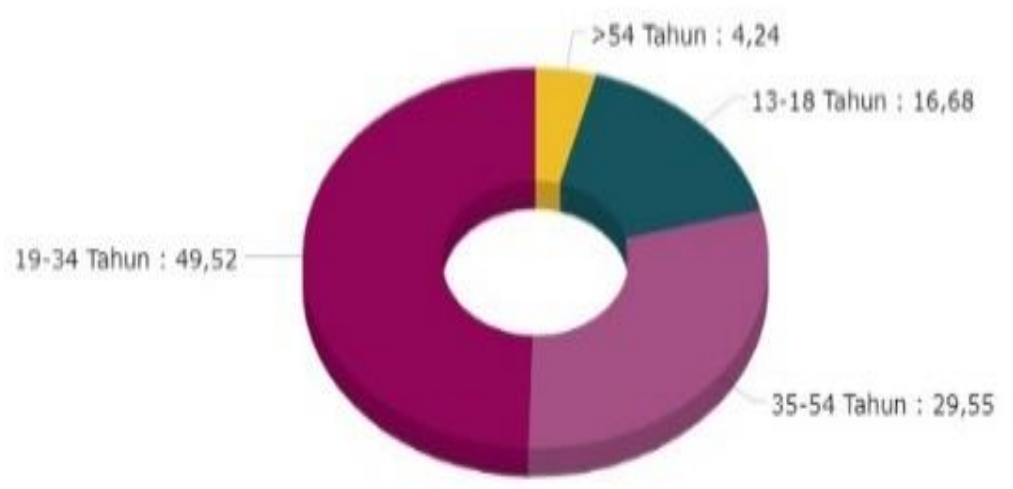

Satuan : \%

Based on Figure 1, it shows that the biggest internet users are in productive age, namely productive age $19-34$ years $(49.52 \%)$ and ages $35-54$ years $(29.55 \%)$, while the smallest area in the 54-year age range and above (4.24\%). Therefore, in the age range of $19-54$ years, they are the most dominant accessing the internet through various devices, both smartphones, laptops, and computers.

Of the millions of internet users, the majority can be assumed to be Muslims, both among millennials and adults, because the population of Indonesia is predominantly Muslim. Based on the results of the Central Statistics Agency (BPS) survey, the following table can be seen: 
Table 1

Indonesian Population Based on Religion 2010-2016

\begin{tabular}{|c|c|c|c|c|c|c|c|c|c|}
\hline $\begin{array}{c}\text { Jenis } \\
\text { Agama }\end{array}$ & 2014 & 2013 & 2012 & 2011 & 2010 & 2009 & 2008 & 2015 & 2016 \\
\hline \multirow{2}{*}{ Islam } & 24325 & 30300 & 25765 & 237710 & 23737 & 23765 & 21917 & 24325 & 25661 \\
\hline & 02 & 12 & 76 & 4 & 20 & 76 & 52 & 02 & 74 \\
\hline Katholi & 11670 & 11471 & 12278 & \multirow{2}{*}{148715} & 14524 & 11912 & 14632 & 116,70 & 120,80 \\
\hline k & 3 & 7 & 7 & & 0 & 1 & 0 & 3 & 4 \\
\hline \multirow{2}{*}{ Kristen } & 26660 & 64871 & 17220 & \multirow{2}{*}{295714} & 29518 & 27953 & 23651 & 26660 & \multirow{2}{*}{275,72} \\
\hline & 8 & 7 & 00 & & 6 & 9 & 5 & 8 & \\
\hline Hindu & 8436 & 18146 & 92520 & \multirow{2}{*}{$\begin{array}{c}27314 \\
48433 . \\
00\end{array}$} & 27115 & 11665 & 32458 & 8436 & 8407 \\
\hline Budha & 45150 & 36611 & 54083 & & 48824 & 54083 & 46941 & 45150 & 45371 \\
\hline $\begin{array}{c}\text { Konghu } \\
\mathrm{cu}\end{array}$ & 389 & 13 & - & 396 & - & - & - & 389 & 500 \\
\hline Lainnya & 171 & 346 & - & 955 & - & - & - & 171 & 177 \\
\hline \multirow{2}{*}{ Total } & 28699 & 38485 & 45679 & 285019 & 28900 & 28409 & 26539 & 27533 & 26210 \\
\hline & 59 & 62 & 66 & 8 & 85 & 84 & 86 & 73 & 26 \\
\hline
\end{tabular}

Saurce: Badan Pusat Statistik, 2018

From table 1 above, it can be understood that Indonesian Muslims are the largest population of the inhabitants of the archipelago, even though from year to year it has decreased. Thus it can be assumed that the most dominant Muslims access the internet with a variety of content. Therefore, in this domain, Repblika.co.id. want to take a more functional role to carry out digital preaching movements or E-Da'wah by displaying the rubric of Islamic Digest. Da'wah through digital provides a change in space and time and the emergence of new values in society (Rahim, Khidzir, Yusof \& Saidin, 2018). Yasraf Amir Piliang (2012) even tracks changes in ritual religion in the cyber era and shows that cyberspace offers a new way of accommodating functions, roles, and activities related to religious rituals (Zulhazmi \& Hastuti, 2018).

Sukayat's research (2009) shows that the internet is a new space in the process of transmitting Islamic messages. This is supported by the characteristics of the internet as a medium that allows everyone to be connected globally. At this point, Saefulloh (2012) considers that e-da'wah or cyber-da'wah as an alternative space that can convey Islamic da'wah with broad reach.

Meanwhile, Yoga (2015) states that the presence of the internet brings fresh angina in the process of Islamic da'wah. The internet forms a Muslim community that takes place in the form of virtual social relations. This was confirmed by Arifuddin (2016) that the advantages of the internet as a medium for contemporary propaganda have advantages in terms of efficiency, accessibility, reachability, and openness. The internet as a medium for da'wah is seen as effective in the activities of Amar Maruf Nabi Munkar, Mazaya (2019) 
considers that Da'wah on the internet can be oriented by counteracting narratives of hoax messages, hate speech and Islamophobia.

Rustandi (2019) added that cyber preaching can be done not only by showing institutional authority but also by every person personally has open access in the process of implementing Islamic da'wah. Meanwhile, Muhammad (2019) examines the face of Islam in social media in the era of Disruption 4.0 from the perspective of prophetic journalism. In his view, digital preaching 4.0 took place through a massive propaganda process. Where the dissemination of the message of Islam is sometimes mixed with provocative messages. Therefore, digital propaganda becomes a necessity, one of which is by promoting good journalism (prophetic) oriented to peace and other good values.

Republika.co.id. will always be consistent in presenting the digital preaching of Islam Digest in front of the segment of its readers, by raising interesting themes and language that is readable. Because of the management of Republika.co.id, well aware that digital propaganda displayed through the rubric of Islam Digest will compete with thousands and even hundreds of thousands of other digital media propaganda online. This is where creativity and new innovations from management are needed so that the E-Da'wah Islamic Digest will always be loved by loyal readers. Rizki (2018) considers that when a mass media displays Islamic rubrics can be seen as a significant role in the actualization of the progress of Islamic civilization. Therefore, the existence of an Islamic Digest in the Republika.co.id media channel can be seen as a concept of contemporary Islamic propaganda that seeks to disseminate Islamic propaganda with narratives that can be understood by Muslims.

At this point, research on journalism literacy by analyzing the presence of the Islamic Digest rubric in Republika.co.id becomes important as an effort to explore the process of dissemination of Islam which today often utilizes digital technology. So, the concept of E-Da'wah can be explored maximally as one of the references in the process of transmitting Islamic messages digitally. This study aims to analyze and understand the mission carried out by the Republika.co.id Islamic Digest E-da'wah is selected reference sources, Islamic Digest E-da'wah contents, and the Islamic Language Style Digest, and audience response to Islamic Digest Republika.co.id.

\section{RESULT AND DISCUSSION}

\section{The mission of E-Da'wah Islam Digest}

The vision carried by E-Dakwah Repubika.co.id. is modern, moderate, Muslim, nationalistic, and popular, while its mission is as a new society newspaper that is advanced, intelligent, and civilized. This vision and mission are ideal and have the mandate of modernity, moderation, Islam, Indonesianness, and publicity. Modernity means that the Republika Public Daily online media wants to build 
an image as a modern media that is present in the latest age children, both present in the real world and cyberspace.

Then moderation means that Republika.co.id will always display the EDa'wah Islamic Digest in the position of siger tengah or washatiyah media (moderate) that is the online media preaching that supports all religious groups, both modernist and traditionalist. Likewise, the Islamic vision is oriented to convey Islamic moral messages that originate in the Koran and al-Hadith. Whereas the national vision is aimed at Republika.co.id. always consistently build the spirit of nationalism and Indonesian-ness, love of the motherland, and love of the Republic of Indonesia. Likewise the people's vision as the personification of Republika.co.id. towards the interests of the people and very concerned with the screams of the people's hearts.

The Islamic, national and populist vision that was carried by Republika since its founding in 1993 until now will continue to be a guide for press members who work at Republika, both for its leaders and employees at the lowest level. Therefore, whomever the leader is, regardless of his background, still carries that vision. Because Republika's presence was the culmination of the long efforts of Muslims, especially young professional journalists led by former Tempo reporters, Zaim Uchrowi has taken various steps for the publication of the Republika public Daily after receiving a recommendation from President BJ. Habibie as the current Chair of ICMI (Period 1992-1997).

While the mission carried Republika.co.id. intelligent, advanced, and civilized means that Republika has a noble goal which is to participate in educating the life of an advanced and civilized nation. To advance the nation, news portals that are of interest and enlighten the reader segment are designed, both through the mainstream media and through social media including the Islamic Digest online propaganda. E-Da'wah Islamic Digest has become a favorite channel for its readers. Therefore, the management is always creative in looking for themes that appeal to the lovers and readers of Islam Digest faithful. This is an effort to maintain the quality of reporting and maintain the dignity of the Islamic Digest.

Thus, management always increases its professionalism by assigning professional people according to their competencies, with the principle of "the write man and the write please." This means that people assigned to the Islamic Digest channel are people who have talent on the channel. By working with professional people, the quality of the content and appearance will be more attractive and appear more authoritative, so that the existence of Islam Digest Republika.co.id. will always be in the hearts of the people.

However, because the Islamic Digest channel of Republika.co.id preaches through online media, the management will adjust to the characteristics of new 
media. As, Mark Poster in, The Second Media Age (1990) states that new media where interactive technology and network communication, especially cyberspace will change society (Littlejohn \& Foss, 2012: 413). Likewise, Denis McQuail (2011: 43) argues that "the main characteristic of new media is the existence of interconnectedness, access to individual audiences as recipients and senders of messages, their interactivity, the diverse uses of an open character, and their nature is everywhere, whether or not depends on location. "

The opinions of Poster and McQuail above, emphasize that the new media (New Media) is more interactive and creates a new understanding of personal communication. The new media according to Littlejohn \& Foss (2012: 414), "is not like face-to-face interaction, but provides a new form of interaction that brings us back to the relationship that could not be done by the previous media." Therefore, E-Da'wah Islamic Digest, adapts to this new media, by preparing open spaces in cyberspace to interact with one another, or someone with the public through the internet network. In the internet network, Nasrullah (2018: 94) states that the audience has been involved and is part of the production to the dissemination of content or referred to as audience participation.

Thus, propaganda through the internet or online propaganda, then the position of the virtual public (cybercommunity) is not only an object of preaching but also as a subject of da'wah. This means that every audience has open space and time to interact with the first source in carrying out the da'wah process. According to Bell (2001); Castells (2001); Johnson (2009); and Jordan (1999) that the character of interactive social media, open in creating content, to a wide network provides a kind of confirmation that the relationship is like two sides of a coin. On the one hand, the media as an institution provides devices and applications that can be regulated on the internet; on the other hand, audiences who fully create content and utilize media tools according to their own needs (Nasrullah, 2018: 95). Therefore, in this context, the Islamic Digest's online da'wah opens space and time to all audiences. Because in new media (internet) the position of the audience is equivalent to the first source. It can receive information and convey information, meaning that there is a reciprocal relationship between the first source and the audience dialectically.

\section{Source of Islamic Content Digest}

Content sources for Islam Digest Republika.co.id. taken from a variety of classical and modern literature. Classical literature is mainly derived from the main sources of Islamic teachings, namely the Koran and al-Hadith as well as the classic books of earlier scholars. While modern literature is in the form of books by scholars and contemporary intellectuals on various fields of life, ranging from issues of aqidah, fiqh, morality, social, economic, education, history, 
and others. These sources, as a reference for Republika's management in displaying Islamic Digest content in each publication.

However, according to Irfan (interview, Feb. 2020) said that: "Technically, the sources that we prioritize are the sources obtained from the results of reportage or the work of journalism. Usually, interviews are conducted with people who are competent in their fields."

Then to complete it, the management opens the literature from the classic books that refer to al-Quran and al-Hadith. But the main menu is still the result of the report. Direct reports or reports are taken from translations or from news agencies that are subscribed to Republika. There are also other sources, namely the organizers of Islamic mass organizations that send content to Repubika.co.id management.

From these sources, the Islamic Digest reporter chose the main themes that are interesting and actual to meet the needs of new media audiences (cybercommunity). In new media (according to McQuail (2011: 43)) there is interdependence, access to individual audiences as recipients and senders of messages, interactivity, diverse uses, as open characters, and their nature is everywhere or does not depend on location. Nasrullah (2018: 95) explains that "audiences in online media have been involved and become part of the production to the dissemination of content or referred to as audience participation. However, engaging this audience does not mean the audience has full power in producing content. Audiences remain in the outer circle of media institutions and not all content can engage audiences."

Besides, another source that is used as a reference for Islamic Digest is to raise multi-dimensional phenomena that occur in society, both local Indonesian people and the world community. For example, the corruption of high-ranking officials in Indonesia, which is never lonely, landslides, and floods across the country, the coronavirus outbreak in Wuhan City, Hubei Province, China, and others. Islam Digest raised the case, not in its political aspects, but presented it from its moral and legal perspective. A moral perspective becomes very important, to demand the people/audience why the disaster happened? What is wrong with this country? What is the solution to dealing with these calamities? And what is the Islamic perspective on the event or disaster? So cyberspace da'wah can take ibrah or lessons from these calamities.

These phenomena are the source of Islamic Digest propaganda content, which is chosen by reporters as journalistic work. The Islamic Digest reporters will choose and sort out, which events get the attention of many parties and are relevant to the current conditions. Then the reporters consult with management for approval. This is where Republika management runs well. So the reporter does not run one-man shaw but works according to standard operating 
procedures (SOP) set by Republika management. Republika management applies policies using a process model. Process model (Process Model) is a government or organizational policy by making policy through a process that consists of a series of political activities (Suratman \& Salamah, 2019: 265).

The policy process consists of problem identification, formulation of policy propositions, policy legitimation, policy implementation, and policy evaluation. This process policy model is practiced by Republika, both in print media publishing and online media publishing including Islam Digest. So that the existence of Republika is still established today when the onslaught of other media continues to grow like mushrooms in the rainy season.

Moreover, competition in online media digital propaganda is more lively and unstoppable, in harmony with the increasingly open expression and creativity through mass media and social media. Therefore, Republika which manages two media at once, namely print media and social media, makes every effort to maintain its existence for the livelihood of many people, from the chief editor to the cleaning service. To that end, togetherness is built between all elements involved, by applying the wisdom of the process model.

\section{Islamic Content Digest}

About Islamic Digest content published in Republika.co.id covering various Islamic matters, such as Aqidah, sharia/fiqh, moral/historical Sufism, and others. These contents, are very important to be presented in the rubric of Islam Digest because they are very relevant to the needs of the Muslim audience or readers who are loyal to Republika.co.id. since the launch of the rubric. If the content is previewed, during January and February 2020, the following table can be seen:

Figure 2 Islamic Content Digest Republika.co.id on January to February 2020

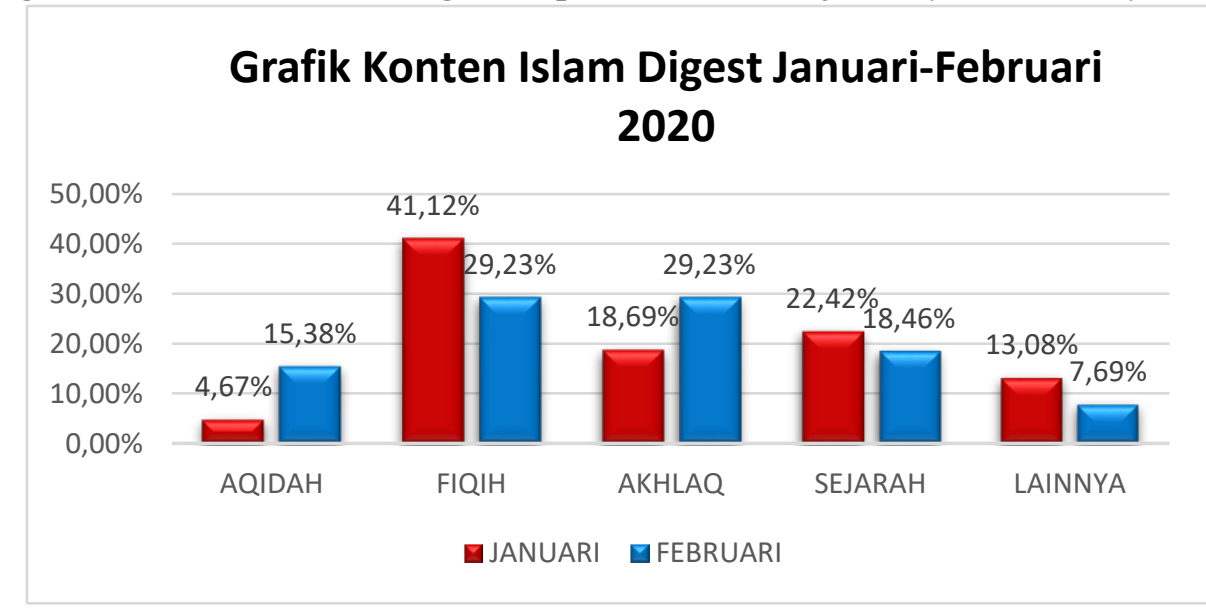

Source: Islam Digest Republika.co.id.

Researcher's Illustration, Februari 2020. 
Figure 2 above, shows that the content of E-Da'wah Islam Digest shows more about fiqh issues which reach $36.62 \%$. It can be understood that the management of Republika.co.id. very well understand the needs of the Muslim audience in Indonesia. So that the content about fiqh or sharia gets a bigger portion because the public needs more information about fiqh issues that are deeply in contact with the procedures of worship and the law. In this context, Islam Digest Republika.co.id wants to connect the content presented to the needs of the audience. This is relevant to what Rogers put forward (Liitllejohn \& Foss, 2012: 455) that he links dissemination with the process of social change that consists of discovery, information dissemination, and effect. This is an implication of the diffusion of innovation in the process of spreading Islamic messages in the mass media. In other words, from the spread of Islamic content information through the internet there will be significant changes for the public in understanding and practicing their religious teachings.

The second portion that gets the attention of Management is the content about morals or Sufism by $22.67 \%$, and history $20.93 \%$. In this context Republika.co.id. has a vision that is inviting readers to always beautify the noble character that has been exemplified by the Prophet Muhammad. Because the best example, as indicated by Allah SWT, in the Koran reads, "Surely there has been found in (the Prophet's) self a good role model for you (QS. Al-Ahzab: 21)." Then the content about history is intended to enlighten the public about past events that elevate the glory and excellence of Muslims in various fields of life, starting in the fields of science, thought, economics, politics, social culture, and others. The historical content is also a reference for Muslims, that Islam in its journey has always experienced fluctuating struggles, since the time of the Messenger of Allah, the Companions, the Tabiin, the Tabiit Tabiin, to the struggle of Mutaqaddimin and Mutaakhirin Ulama.

While the content of aqidah is $8.72 \%$ and the other $11.04 \%$. Aqidah content is related to the faith and belief of people towards their Lord. Islam Digest also wants to instill aqidah to its readers, so that the Islamic community istigomah in believing in Allah SWT, following his Word: "Those who say," Our Rabb is Allah, "when they affirm their stand, then angels will descend to them (by saying), "Do not be afraid and do not be sad; and cheer you up by getting the heaven that you have been promised. " (Surah Fushilat [41]: 30). Reiterated by the words of the Prophet Muhammad, "Kul amantu billah summastakim ..." means: Say I believe in Allah and rest. (HR. Muslim). If the faith of the people is maintained from the attitude and behavior of shirk (associating partners with Allah), then the faith of the people will be saved, and be in the true faith. Therefore, Islam Digest Republika.co.id takes a role in the domain, to maintain the aqidab of the people, even though the percentage is not as big as the fiqh 
content.

These contents are content that is needed by the people at this time so that Islam Digest adapts to the interests and needs of the people. However, the existence of the Ummah or public in digital propaganda is not the same as the propaganda in the real world. Da'wah in cyberspace (cybercommunity) mad'u position not only acts as an object but can also act as a subject. This means that preaching audiences have space and time to interact with the Islamic Digest online media. Because of the word Nasrullah (2018: 73), audiences have been involved and become part of the production to the distribution of content or called audience participation. Therefore, moral messages in Islam Digest open up space and time for the audience to provide feedback, both positive and negative feedback.

Thus, content in Islam Digest Republika.co.id is renewable content through the internet network. According to Nasrullah (2018: 73), "new content is a social-cyber reality that arises from the communication interactions of internet users. Like in the real world, in the virtual world text becomes an interchangeable message. The message uses a facility or medium which in this discussion is a computer. The term computer-mediated communication or computer-mediated-communication (CMC) is the most popular term to show how communication takes place with computer technology intermediaries. "

Content characteristics in Islam Digest consistently display Islamic content that is soothing, peaceful, and tolerant. This is relevant to the teachings delivered by Rasulullah SAW. As the Word of Allah SWT. in the Qur'an, "Wamaa arsalnaka Illa Rahmatan lil Alamin" which means, "And I was not sent to this world only to convey mercy to all nature" (Surah Al-Anbiya: 107). Islam Digest from the Ummah, by the Ummah, and for all Muslims of various groups and sects.

Therefore, Islam Digest will maintain harmony and tolerance among Muslims and other religious communities. As harmony was conceived by Mukti Ali in the New Order Era, with the concept, "Religious Harmony Trilogy", namely: (1) Religious Harmony Internally; (2) Interfaith Harmony Between Religion, and (3) Interfaith Harmony with the Government (Saefullah, 2010: 18). The concept of harmony aims to build peaceful, safe, and peaceful religious relations. So that the development that was being carried out by the government at that time was expected to be no interference from anywhere, including from religious groups. If the condition of the community is safe, peaceful, and peaceful, then the development carried out by the government at that time will run well, and national development targets will be achieved well.

\section{The Language Style of Islam Digest}

The style of language displayed by the Islamic Digest channel Republika.co.id. is a popular language style. The popular language style is the style of pop. Ngepop 
is known by many people, easy to remember, and easy to read. In terminology, popular language contains three meanings, namely: (1) known and liked by many people (general); (2) according to the needs of the community at large; easily understood by many people: science; (3) liked and admired by many people (KKB, 1991: 782).

According to Irfan (interview, February 2020), that: "Islam Digest chooses popular languages so readers can enjoy the narrative in the rubric. Although sometimes the literature is in a very academic language and the source of the character is very academic, but Islam Digest describes it in a popular language so that all audiences can enjoy the content with enjoyment. "

Irfan's speech, it can be understood that the popular language presented by Islam Digest aims, (1) to reach all heterogeneous layers of the audience because loyal readers of the Islamic Digest are from various backgrounds, both millennial and elderly, both educated and community groups ordinary, both urban and rural communities; (2) to maintain the consistency of reporting, so that Islam Digest Republika.co.id can still maintain its spirit as a quality and modern online media, (3) so that it is easily digested and understood by each reader segment so that the content of Islamic Digest can be an alternative in providing Islamic enlightenment to all loyal readers, (4) to connect the heart of friendship between the Islamic digestive media with audiences and one audience with other audiences, and (5) to affirm the spread of Islam which rabmatan lil'alamiin so that Islam is favored by all groups and other Islamic religious sects.

Thus the use of language in an article becomes the character of a media, including Republika.co.id online media. The characteristics of Republika.co.id media as explained earlier are using popular languages. A popular discussion presented by Islam Digest in order to help the reader segment, both the generation of millennials and the senior generation. Sumadiria (2017: 17) emphasized that journalism works must be familiar to the ears, eyes, and minds of the readers, listeners, or viewers. Journalistic language must be popular, meaning that it is accepted and familiar with all levels of society.

In various theories of language should consider the context of the situation, it is almost indisputable that the extra lingual context is a very important factor in influencing the form of one's language (Wijaya, 2013). This has been proven by Islam Digest Republika.co.id with more and more readers of Islamic Digest from year to year. Based on Republika's editor-in-chief's prediction, that the loyal readers of Islam Digest until 2018 will reach more than 1 million. This means that Islam Digest has been embedded in the hearts of audiences who are always in demand and loved. 


\section{The Audience Response of Islam Digest Rubric}

Public response to the Islamic Digest channel Republika.co.id. since its establishment in 2010 until now, it has been relatively very positive (interview, January 2020). Even the management of Republika is often visited by various layers of the audience for discussion (Focus Group Discussion), both from intellectuals, clerics, students, and ordinary people. One of them was once teachers from Indramayu visited Republika to have a dialogue with the leaders of Republika by bringing Islamic Digest content from the beginning of its publication to enrich learning for their students.

Thus, according to Irfan (Interview, January 2020) that:

"Indeed this Islamic Digest is collectible items, can be collected, can be read at any time, can be enjoyed anytime because the content is everlasting."

In fact, according to Irfan,

"In addition to the FGDs, management often conducts market surveys, and the results are very positive. The readers are very happy with the content presented by Islam Digest, and one of the channels on the online platform that has good traffic compared to other channels. "

Based on Irfan's explanation, that Islam Digest has been embedded in the hearts of the people, so that he is always loved and respected by the people. This is thanks to the creativity and innovation of Republika.co.id management, in packaging and exploring the content presented. Because of management, understanding the content presented on the Islamic Digest channel will continue to compete with similar content from other online media. In addition, the characteristics of the audience on social media have the power to choose and sort the preaching content that they like.

The results of research conducted by Elihu Katz, Jay Blumer and Michael Gurevitch (1974), provide basic assumptions when viewing audiences: (1) audiences are active parties and the use of media depends on the objectives to be achieved; (2) the audience has the flexibility to determine the relationship between the need for satisfaction and the choice of media; (3) the media and the public are not in a vacuum; (4) every audience has full awareness in choosing media; (5) how the relationship of the audience to the media or the content of the media has a different impact on values among the audience itself.

Based on this research it was found that the public had the freedom to determine which media they wanted and what content they liked. In this context, E-Da'wah Islamic Digest always maintains its connection with the audience through interesting, readable, and quality content, so that the response of the already well-built audience will continue to be well maintained. Islam Digest as a feature of Islam will continue to be connected between the first source of Islam Digest with the public (cybermad'u). This phenomenon according to experts, such 
as Brenda Brasher (2001), Hojsgaard \& Warburg (2005) is called cyber-religion. Overall all of these phenomena lead to the phenomenon of cyber-religion which can be practically understood as a phenomenon, where there is a significant relationship between religion and the internet, both as a medium and as a cultural space (Fakhruroji, 2019: 119).

Brenda Brasher (2001) defines cyber-religion as the presence of religious institutions and activities in the cyber world. While Lorne L. Dawson (2000) defines cyber-religion as an organization or religious group whose existence is only in the cyber world. "Whereas Morten T Hojsgaard (2005) explains that there are three different concepts about religion in the online world, namely the existence of virtual communication that replaces real communication (Mediation), no need for a complete religious institution (Organization), and a reflection of cyberculture that replaces reflection of religious traditions (Content).

Thus, moral messages, teachings about God, religious values, and norms that are manifested in cyberspace, including the activities of Islamic preaching Digest Republika.co.id. as part of cyber-religion. The presence of Cyber-religion is an interesting phenomenon for some of humanity. This is in line with the religious enthusiasm of the middle class educated people (middle class) to study religion through the internet. The internet has become an alternative teacher besides formal teachers in schools, even in certain contexts the internet has become a loyal friend who accompanies students and students in doing their schoolwork from their teachers or lecturers.

\section{CONCLUSION}

E-Da'wah Islam Republika.co.id. very quality, interesting, and easy to read according to the tastes of the audience, so it is very popular and loved by the audience of readers. In fact, they are faithful to always follow in the footsteps of the Islamic Digest, where he steps into the audience trailing. Because Islam Digest not only presents quality content sourced from the Koran, Sunnah, and classic books that are trusted, as well as sources from charismatic Islamic figures but also able to exploit academic language styles into popular languages that are can reach all people. This is the professional work of the Islamic Digest reporters who struggle for the benefit of the people and nation.

\section{REFERENCE}

Arifuddin. (2016). Dakwah Through Internet: Challenges and Opportunities for Islamic Preachers in Indonesia. Ar-Raniry: International Journal of Islamic Studies,3(1).

Atmadja, N. B., \& Ariyani, L. P. S. (2018). Sosiologi Media Perspektif Teori Kritis. 
Depok: Raja Grafindo Persada.

Fakhruroji, M. (2019). Dakwah di Era Media Baru: Teori dan Aflikasi Dakwah di Internet. Bandung: Simbiosa Rekatama Media.

Ibrahim, I. S., \& Yosal, I. (2014). Komunikasi Yang Mengubah Dunia. Bandung: Sembiosa Rekatama Media.

Littlejohn, S. W. \& Foss, K. A. (2012). Theories of Human Communication, 9th.ed. Jakarta Selatan: Salemba Humanika.

Mazaya, V. (2019). Cyberdakwah sebagai Filter Penyebaran Hoax. Islamic Communication Journal, 4(1).

McQuail, D. (2011). Teori Komunikasi Massa. McQuail, Edisi 6 Buku 1. Jakarta: Salemba Humanika.

Muhammad, F. (2019). Diseminasi Dakwah Era Disrupsi 4.0 dan Literasi Media Sosial (Perspektif Jurnalisme Profetik). Jurnalisa: Jurnal Jurusan Jurnalistik, 5(2), 196-210.

Nasrullah, R. (2018). Media Sosial: Perspektif Komunikasi, Budaya dan Sosioteknologi. Bandung:Sembiosa Rekatama Media.

Rahim, N. N., Khidzir, N. Z., Yusof, A. M., \& Saidin, A. Z. (2018). A Model of Islamic of Islamic Animated Infografhic as an Inovation, Jurnal JCIS, 4(2).

Rustandi, R. (2019). Cyberdakwah : Internet sebagai Media Baru dalam Sistem Komunikasi Dakwah Islam, NALAR: Jurnal Peradaban dan Pemikiran Islam, 3(2), 84-95.

Rustandi, R., \& Hanifah, H. (2019). Dinamika Dakwah Komunitas Remaja Islam di Pangelangan, Jurnal ANIDA (Aktualisasi Nuansa Ilmu Dakwah), 19(2), 199-224.

Rizki, J. W. S. (2018). Peran Media Massa dalam Reaktulisasi Kemajuan Peradaban Islam (Analisis Wacana terhadap Rubrik Mimbar Jum'at di Surat Kabar Harian), TAZKIR: Jurnal Penelitian Ilmu-ilmu Sosial dan Keislaman, 4(1), 64-78.

Saefulloh, Aris. (2012). Cyberdakwah sebagai Media Alternatif Dakwah. Islamica, $7(1)$.

Sukayat, T. (2009). Dakwah Melalui Internet: Kajian tentang Manajemen Penyebaran Informasi dalam Dakwah. Prophetica, 1(1).

Sumadiria, H. (2017). Bahasa Jurnalistik: Panduan Praktis Penulis dan Jurnalis. Bandung: Sembiosa Rekatama Media.

Suratman, H., \& Salamah, U. (2019). Hukum dan Kebijakan Publik. Bandung: Refika Aditama.

Wijaya, I. D. P. (2013). Pemakaian Bahasa Dalam Karya Ilmiah Populer, Journal Arbitrer, 1(1).

Yoga S, S. (2015). "Dakwah di Internet: Konsep Ideal, Kondisi Objektif dan Prosfeknya” dalam Al-Bayan, Vol. 21 No. 31, Januari-Juni 2015. 
Zulhazmi, A. Z., \& Hastuti, D. A. S. (2018). Dakwah, Muslim Millennials and Social Media, Jurnal Lentera, 2(2). 